\title{
Characteristics of the Language of Women in English
}

\author{
Qiuling Bi \\ College of Humanities, Binzhou Medical University, Yantai, China \\ E-mail: bqlsherry@163.com
}

\begin{abstract}
This study researches the characteristics of the language of women in English in terms of sociolinguistics. It embraces phonology, specialized vocabulary, communication, grammar. In phonology, features of the language of women are mainly present in pronunciation, tone, pitch. Vocabulary of women is more abundant, polite and euphemistic than men. The features of the language of women contain intensifiers and exaggerated adjectives, interjections, nicknames or diminutive and color words. In communication, it contains speech style and communicative strategies, amount of speech and conversational topics. Women usually use following grammar structures: tag questions, modulation, embedded imperatives and euphemism.
\end{abstract}

Index Terms - women language, characteristics

\section{INTRODUCTION}

As we all know, when different genders speak the same language, even express the same contents, they will use different expressional approaches. Through this research, we know how the language of women changes along with society changes in terms of their social positions, social culture and social customs etc. The purpose of this paper is to discuss the characteristics of the language of women in English in terms of sociolinguistics. Sociolinguistics is the subdiscipline of linguistics that studies language in social contexts. It is concerned not only with the language use in different speech communities including regional, ethnic and social groups, but also with the impact of extralinguistic factors on language use, such as gender, profession, and social and so on. If we understand the characteristics of women's language, we can learn of the relationship between social development and language.

This paper focuses on the characteristics of the language of women. It can be concluded as following: phonology, specialized vocabulary, communication and grammar.

\section{PhONOLOGY}

In phonology, features of the language of women are mainly present in pronunciation, tone, pitch.

\section{A. Pronunciation.}

Linguists found that women's pronunciation is more standard than men. In terms of whether the pronunciation is correct or wrong, women always keep their high sensibility in correctness. They often use standard, clear and authoritative pronunciation in order to keep their identity and social status. At the same classroom, the ESL female students will learn English better and quicker than ESL female students.

\section{B. Tone.}

In verbal conversation, falling tone expresses the affirmation while rising tone expresses the suspicion or expectation. Generally, women like modulating the intonation, speed and volume when they speak. In some specific situations, women like to use rising tone to answer the interrogative sentences, even at the end of declarative sentences. ${ }^{[2]}$ This means on the one hand, women want to show their politeness and softness, on the other hand, they show their vacillation and nonconfidence in doing something. For example:

Husband: When will dinner be ready?

Wife: of ... around six o'clock?

In this example, obviously wife is cooking and she knows when the dinner can be ready, but she answers her husband with rising tone to show that she is very gentle.

\section{Pitch.}

High pitch is one distinguished feature of the language of women and they usually speak in high pitch than men due to the biological factors.

\section{SPECIALIZED VOCABULARY}

Generally speaking, vocabulary of women is more abundant, polite and euphemistic than men. The features of the 
language of women contain intensifiers and exaggerated adjectives, interjections, nicknames or diminutive and color words.

\section{A. Intensifiers and Exaggerated Adjectives.}

Many researches show that women often use them to strengthen what they want to express, such as, adorable, charming, cute, so, such, quite, awfully, perfectly etc. Women usually say: "John smokes a lot of cigarettes a day." Men just say: "John smokes a pack of cigarettes a day." "[3] Another example: "I had such fun yesterday at the party."

\section{B. Interjections.}

Women are more implicative, cautious, gentle and polite than men, so their language is more elegant. "Even when they are disgruntled or unpleasant, they usually do not use coarse words but euphemism, such as, damn, shit, fuck, etc." ${ }^{[4]}$ When they express surprise, they often use "Oh, dear.", "Dear me.", "Good heavens.", "My God."

\section{Nicknames or Diminutives.}

Women like to add suffix "-y" or "-ie" to some words to express close relationships with others (such as, auntie, sweetie) or leave their cute impressions (such as, cookie, panties, birdie). They usually say: "What a lovely doggie!" "The birdie is flying in the sky."

\section{Color Words.}

Women are sensitive in color. They are good at using some color words by describing colors, like "chartreuse, beige, mauve, lavender, azure ${ }^{[2]}$ and so on.

One professor conducts an experiment. He puts different boards with 20 different colors on a blackboard and let students write out the names of color. The result is that female students can write out $71 \%$ of the names and male students only write out $46 \%$. Then he let them to distinguish five groups with familiar colors and each group contains two. The result is female students can write out $63 \%$ of the difference and male students can write out of $40 \%$.

\section{COMMUNICATION}

\section{A. Conversational Topics.}

In western countries, many of women are housewives, therefore, their conversational topics are traditionally focused on personal relationships including personal feelings, housework, clothes, children, families and so on.

\section{B. Amount of Speech.}

Generally, people have a fixed opinion that women are more talkative than men. "In the dictionaries, there are plenty of descriptions to describe this characteristic: chatter box, gossip, babble or prattle and so on" [2]. Actually, it is not always the fact. So far almost researches' conclusions are the opposite. In the most conversations, including on the street, at the families or hotels, at the party or some social activities, men talk more than women, esp. the dialogue between men and women.

Why does this situation happen? One explanation is that double standard existed between the men and women. Society prescribes that women should talk little, or else they will be thought they are impolite and flirtatious, even though women talk less than the men but beyond the limits.

\section{Speech Style and Communicative Strategies.}

When women talk with others, they are supportive and cooperative talkers. They are interrupted by men during the speech and usually act as hearers by some minimal responses, such as, "mm", "hmm", "um", "huh" or "yeah" to express their attention to others' speech. So women tend to keep the continuity and fluency of the communication, seldom interrupt others' talking or challenge other's opinions directly. When they want to do so, "they will say: "I'm sorry" or "Excuse me". In public or during the conversation process between men and women, women tend to keep silence $"[4]$.

\section{GRAMMAR}

Women usually use following grammar structures: tag questions, modulation, embedded imperatives and euphemism.

\section{A. Tag Questions.}

This kind of sentence pattern has a strong meaning of appeal as well as inquiry which function as polite and implicit expressions. For example:

a. Mary is a nice girl, isn't she?

b. Bob can't finish that job, can he?

We can see that tag question plays an important role in the social communication and it makes the interlocutors engaged in the conversations.

\section{B. Embedded Imperatives.}


Women use this kind of polite sentence pattern to ask others to do a favor. For example: "Will you please open the window?"

\section{Modulation.}

This is a very inobtrusive sentence pattern. It not only "expresses a tentative requirement or a suggestion, but also avoids direct reaction at that time" [4]. It contains some hedges, such as, "I guess", "I think", "I suppose", "I'm afraid" and etc. These expressions convey the information that the speaker is uncertain about what s/he is saying, or can not ensure the accuracy of the statement. For example: When women express I must go, they usually say: "I am afraid it is time for me to be going."

\section{Euphemism.}

In the conversations, women prefer to use it to express their opinions. For instance:

Mary: What do you think of the color of my dress?

Nancy: It's interesting.

In this dialogue, Nancy's response implies that she don't like the color of the dress.

In addition, women tend to use hypercorrect grammar structure, so they seldom use nonstandard multi-negative structure. They will not use “ain't” or “go in”. Another example: I don't want none.

\section{CONCLUSION}

Long time ago, there existed gender discrimination in the society which influence the language usage. Women are treated as powerless or weak sex, as a result, it is natural for people to think their language is a weak language. At that time social language is sexist. To a large extent, people held negative attitudes toward the language of women. Later, with the development of Women Liberation Movement, women's social position is changing. Feminists begin to challenge women's powerless social status in many aspects, including language usage. "They not only realize the negative images of the language of women, like being trivial, gossip and weak, but also analyze some factors which shape the image of from the perspectives of women's social status" [1].

The language of women is powerless, because women, who live in this male-dominated society, are bound to powerless, secondary and subordinated in social status. With women's social, economic and cultural development, women have stepped into society. Many women work with men in many fields and have made great achievements. They know outside world better and better. All in all, the language of women and men inter permeated each other. Social work makes women more confident in conversation and more skilled in linguistic skill. With the development of social civilization, the difference is becoming smaller and smaller between different genders and finally it will gradually vanish. The early impression of language of women as deferential, inferior, deviant, powerless and submissive will be gradually thrown away.

To sum up, although the language of women is thought weak, empty, gossipy, powerless and deviant, it has many positive features: standard, elegant, affectionate, polite, supportive, cooperative and expressive. It is believed that with the social development, the language of women will be widely advocated and not be discriminated. Meanwhile, it will not have much difference compared with men.

\section{REFERENCES}

[1] Chen Hongmei. (2005). On the Image of Women's Language in English, Foreign Language and Foreign Language Teaching, 53.

[2] Huang Hongrui. (2003). The Representation of Gender Difference in Language, Journal of Zhejiang University of Technology (Social Science ), Vol.2, 214.

[3] Ncwmeyer, Frederic (ed) (1988). Linguistics: The Cambridge Sunrey. Vol IV, Language, The Social-cultural Context, Cambridge: CUP, 104.

[4] Zhang Congjiang. (2004). The Characteristics of Women of Language. Journal of Qiqihar University( Phi \& Soc Sci), 79-80.

[5] Zhuang Xueyun. (2001). The Language Divergence of English. Culture Research, 140.

Qiuling Bi was born in Binzhou, China in 1981. She received her M.A. degree in English Education from The University of Wisconsin - Platteville, USA in 2007

She is currently a lecturer in the College of Humanities, Binzhou Medical University, Yantai, China. Her research interests include sociolinguistics, English vocabulary teaching and multimedia English teaching. 